\title{
МИГРАЦИЯ ИЗ СЕЛЬСКОЙ МЕСТНОСТИ В ГОРОДСКИЕ ПОСЕЛЕНИЯ В СССР В 1920-е ГОДЫ
}

\author{
ВАЛЕНТИНА МОИСЕЕНКО
}

\begin{abstract}
Цель статьи - показать возросшую роль мигращии населения из села в город после перехода к нэпу и с началом форсированной индустриализации и коллективизации; большое внимание уделяется инструментам административного регулирования миграџии, опыт использования которых сыграл существенную роль в изменении миграционной политики в начале 1930-х годов.
\end{abstract}

Ключевые слова: миграџия населения, либерализаџия передвижений населения, удостоверение личности, прописка населения, учет миграџии, урбанизаџия, первая пятилетка развертывания народного хозяйства.

\section{ЛИБЕРАЛИЗАЦИЯ ПЕРЕДВИЖЕНИЙ}

В оценке характера миграции в 1920-е годы существенную роль играет учет довоенных тенденций этого процесса, так же как условий, вызванных коренными изменениями общественного устройства после октября 1917 г.

Известно, что значительный приток населения в столичные города (в основном крестьян) отразили городские переписи населения второй половины XIX века, проведенные в С.-Петербурге, Москве и ряде других городов. «Чрезвычайный прилив крестьян в города» в размере около полумиллиона крестьян ежегодно был определен как один из важных итогов Всероссийской переписи населения 1897 г. Миграция в города оценивалась как «настоящее повальное бегство мужика из деревни, всех последствий которого невозможно предвидеть» [Михайловский 1897: 116-117]. Переписи и данные текущего учета населения свидетельствовали об ускорении в конце XIX века урбанизации страны. Но в результате увеличения естественного прироста сельского населения города за время после 1861 г. до конца XIX века миграция в города поглотила только 9,6\% естественного прироста сельского населения, в том числе миграция в города Европейской России - 9\%. Приток избыточного сельского населения в города за эти годы в отличие от стран Западной Европы сравнивался с «маленьким озерком, с трудом вмещавшим в себя струю жиденького потока, приливавшего из деревни» [Огановский 1914: 31]. В 1905-1910 гг. ежегодно в города Европейской России прибывало 351 тыс., в следующие 4-5 лет - примерно 470 тыс. человек [Огановский 1914: 43]. По другим данным, приток в города за 1897-1914 гг. в среднегодовом исчислении составил около 330 тыс. человек [Михайловский 1923: 24].

\footnotetext{
ВАЛЕНТИНА МИХАЙЛОВНА МОИСЕЕНКО (mvm.msu@gmail.com), МОСКОВСКИЙ ГОСУДАРСТВЕННЫЙ УНИВЕРСИТЕТ ИМ. М.В. ЛОМОНОСОВА, РОССИЯ.
}

СТАТЬЯ ПОСТУПИЛА В РЕДАКЦИЮ В АПРЕЛЕ 2018 Г. 
Новый этап урбанизации с конца XIX века в России был связан с признанием ее развития по западно-европейскому пути. Как особый вид миграции из деревни в город, дополнявший приток «на постоянное проживание в городе», рассматривался неземледельческий отход крестьян на заработки. Но глубокий анализ урбанизации сдерживали отсутствие регулярных переписей населения и состояние текущего учета миграции. Решение последней задачи затрудняла архаичная паспортная система, сохранявшаяся в отличие от большинства стран Западной Европы в России «из-за обширности территории и трудностей обеспечения охраны страны средствами полиции» [А.Я. 1897: 924]. В то же время стремление ослабить негативные последствия паспортной системы проявились в отмене фискальной функции паспорта (1897 г.), необязательности паспорта в местах постоянного проживания, за исключением столиц, и при перемещении сельских жителей в пределах своего уезда на расстояние не свыше 50 верст [Дерюжинский 1919: 50-51]. Возможность полного учета внутренней миграции (механического движения) затрудняло также наличие разных видов паспортов у разных групп населения, существование «черты оседлости». К тому же целесообразность организации текущего учета миграции, учитывая еe разнообразные виды, оценивалась критически исчерпывающий контроль передвижения считался стеснительным для населения и стоил бы несоразмерно дорого [Воблый 1924: 271].

Сложившийся ход урбанизации был прерван Первой мировой и гражданской войнами, а также голодом 1921-1922 гг. Отмена правовых институтов дореволюционной России после октября 1917 г. означала необходимость определения отношения государства к внутренним и внешним передвижениям населения, введению новых документов, удостоверяющих личность, организации новой системы учета населения и др. Во время военного коммунизма и гражданской резко усилилась роль административных методов регулирования внутренней и внешней миграции, основой которого стала всеобщая трудовая повинность и введение трудовых книжек для нетрудящихся [СУ 1918: №73: Ст.792: 1003-1005]. В 1919 г. трудовые книжки, введенные в Москве и Петрограде и служившие удостоверением личности, были затем распространены на все население РСФСР, достигшее 16 лет [СУ 1919: №28: Ст.315: 447-448]. Негативные последствия административного регулирования передвижений в 1917-1921 гг. оказались долговременными. Однако переход к нэпу потребовал либерализации законодательства, регулировавшего внутреннюю и внешнюю миграцию. В 1922 г. всем гражданам было предоставлено «право беспрепятственного передвижения по всей территории РСФСР в черте ее федеральных границ до пределов пограничных пунктов» [СУ 1922: №11: Ст.106: 201-202], ${ }^{1}$ сыгравшее положительную роль в восстановлении экономики и функционировании рынка труда. В 1922 г. стали действовать также новые правила выезда за границу граждан РСФСР и иностранцев [СУ 1922: №34: Ст.401: 784-786]. В последующие годы были приняты законы, определявшие политику государства в отношении отхода крестьян на заработки, планового переселения в многоземельные районы, перемещений специалистов в отдаленные районы и др. Характерно то, что эти

\footnotetext{
${ }^{1}$ В данном случае рассматривается практика РСФСР. Решение аналогичных вопросов в других союзных республиках СССР является самостоятельной задачей.
} 
законы были приняты под сильным давлением «самовольных» (стихийных) передвижений крестьян.

Термин «беспрепятственное передвижение» как правовой институт, судя по практике в последующие годы, не был синонимом термина «свобода передвижения». Помимо использования государством различных административных инструментов (прописки населения, удостоверения личности, вербовки и др.) в регулировании пространственного движения населения, «беспрепятственное передвижение» включало ограничение прав на передвижение ряда групп граждан: современники писали, что личность не являлась чем-то самоценным, и обеспечение ее прав было второстепенным делом [Карадже-Искров 1927: 29-30]. С точки зрения административного права важными были не столько индивид и его правовые гарантии, сколько революционный порядок и гарантии сохранения государства пролетариата [Елистратов 1923: 30]. В первой половине 1920-х годов были приняты законы, ограничивавшие передвижение отдельных групп граждан, ставшие частью карательной политики государства.

С 1922 г. административная высылка (заграницу или в определенные местности РСФСР) стала применяться к лицам, причастным к контрреволюционной деятельности и пребывание которых в данной местности (и в пределах РСФСР) представлялось по характеру их деятельности, прошлому, связи с преступной средой опасными с точки зрения революционного порядка [СУ 1922: №51: Ст.646: 1134; СУ 1922: №65: Ст.844: 1444]. В 1925 г. бывшие помещики и крупные землевладельцы, за исключением ряда льготных категорий, были лишены права на землепользование и проживание в принадлежавших им до октября 1917 г. хозяйствах [СУ РСФСР 1925: №29: Ст.206: 364]. Выселенные лица имели право на земельный надел в губерниях, в которых ранее не имели собственности [Гуров 1927: 17-19].

В то же время «самостоятельные» передвижения населения (приток в города, отход на заработки, переселения) рассматривались как противоречившие интересам государства.

В развитие декрета 1922 г. о «беспрепятственном передвижении населения» были приняты законы, определявшие порядок удостоверения личности и правила прописки населения в городах РСФСР, рассматривавшиеся как инструменты административного контроля передвижения населения.

\section{УДОСТОВЕРЕНИЕ ЛИЧНОСТИ (1923 Г.). ЛЕГИТИМАЦИЯ}

В начале 1920-х годов в РСФСР введения нового документа, удостоверяющего личность, было объективной необходимостью.

Наряду с паспортами дореволюционного образца, в ряде губерний действовали «свои виды на жительство» - трудовые книжки, карточки, паспорта, отличавшиеся между собой и ставившие их владельцев в затруднительное положение при переездах из одной губернии в другую. По приблизительной оценке в начале 1920-х годов в РСФСР существовали девять различных «видов на жительство», не считая документов«суррогатов», выдававшихся жителям отдельных уездов и волостей [Граевский 1927: 41]. 
С 1 января 1924 г. удостоверение личности, единое по форме и процедуре выдачи на всей территории РСФСР, должно было заменить все другие документы, удостоверяющие личность [СУ 1923: №61: Ст.575: 1092-1094]. Во всех случаях, когда гражданам РСФСР необходимо было удостоверить перед органами управления свою личность, достаточно было предъявить письменное удостоверение личности.

По закону 1923 г. органам управления запрещалось требовать от граждан обязательно предъявлять паспорта и иные виды на жительство как стеснявшие право передвигаться и селиться. Право на получение удостоверения личности имел каждый гражданин РСФСР, достигший 16 лет и подавший заявление на его получение. Личность заявителя и достоверность сообщаемых им сведений в городах и поселках городского типа подтверждались актовой (или старой метрической) выписью о рождении, справкой домоуправления о проживании, удостоверением с места работы или службы, в сельской местности - выписью о рождении или справкой сельского совета о проживании. В удостоверении приводились основные сведения о гражданине. Оно выдавалось органами милиции по месту жительства в городских поселениях и поселках городского типа, а также в районах районированных областей и укрупненных волостях, в неукрупненных волостях - волостными исполнительными комитетами [СУ РСФСР 1926: №72: Ст.573: 858].

Паспортная система была сохранена для иностранных граждан, проживавших в РСФСР (СССР), и для граждан РСФСР (СССР), выезжавших за границу.

Следуя инструкции НКВД, получение удостоверения личности было добровольным: граждане не могли быть принуждаемы к получению удостоверения личности. Однако учреждения, выдававшие удостоверения личности, были обязаны немедленно выдать этот документ гражданам, желавшим его получить. Отказ в выдаче удостоверения личности предусматривал особые случаи: если предъявленные документы считались не принадлежащими данному лицу или возбуждали «основательные сомнения в их подлинности или законности» [Инструкция НКВД №370 1925: 248-250].

В 1920-е годы институт удостоверения личности был признан в качестве свидетельства установления в СССР легитимационной системы ${ }^{2}$ [Турубинер 1930: 186]. В 1929 г. утверждалось, что с 1923 г. легитимационная система была принята в стране окончательно. Вслед за РСФСР удостоверение личности ввела УССР [Кобалевский 1929: 202].

Приведенная оценка легитимации основывалась на формальных признаках: признании нового документа, удостоверявшего личность. Однако оценка перспектив легитимационной системы в СССР оказалась ошибочной. Выявившиеся вскоре «грубые извращения» в ее функционировании проявились в отказе милиции отдельных губерний выдавать удостоверения лицам, осужденным по статье 49 УК РСФСР, запрещавшей проживание в определенных местностях, или высланных в административном порядке.

\footnotetext{
2 Легитимационная система (от лат. legitimus - законной, правомерной) - способ удостоверения личности гражданина в государствах, где нет паспортной системы. При легитимационной системе гражданин обязан по требованию соответствующих органов предъявить достаточные доказательства его личности с указанием сведений [Большая Советская энциклопедия 1953: 410].
} 
Кроме того, работники милиции вносили пометки о судимости, высылке, лишении избирательных прав в удостоверения личности [Граевский 1927: 44]. В 1926 г. НКВД РСФСР вынужден был обратить внимание на необходимость выдачи удостоверений лицам, осужденным по статье 49 УК РСФСР, на общих основаниях, на недопустимость внесения каких-либо сведений в удостоверение личности, кроме сведений, предусмотренных соответствующим положением [Циркуляр №365 1926: 264-265].

В 1927 г. «грубые извращения» при выдаче удостоверения личности, как и недостатки работы адресных столов (бюро), объяснялись «консерватизмом аппарата милиции, не способного отказаться от методов, применявшихся в эпоху военного коммунизма», не понимавшего, что «у нас нет паспортной системы, что мы от нее отказались раз и, наверно, навсегда». Отмечалась также неподготовленность к легитимации населения, не уверенного в необходимости получения удостоверения личности и не знавшего правил его получения [Граевский 1927: 44-45].

Недостаток Положения об удостоверении личности (1923 г.) состоял в том, что в нем четко не разъяснялись случаи, при которых закон требовал обязательное предъявление гражданином одного из документов, юридически достаточного для удостоверения личности. Характерно, что после введения прописки в городских поселениях (1925 г.) органы милиции стали требовать от граждан предъявления именно удостоверения личности [Турубинер 1930: 186].

Постановление 1927 г. «Об удостоверении личности» отменило декрет 1923 г. При сохранении удостоверения личности были фактически реанимированы прежние документы, удостоверяющие личность: актовая (или старая метрическая) выпись о рождении или браке, справка домоуправления или сельского совета, расчетная книжка с места работы, членский билет профессионального союза и др. С 1927 г. срок действия удостоверения личности стал неограниченным [СУ РСФСР 1927: №75: Ст.514: 903-907]. Постановление 1927 г. «Об удостоверении личности» было, по-видимому, вынужденным ${ }^{3}$ и одним из последних, в котором регулирование передвижений населения рассматривалось в рамках легитимации. В итоге важнейшая задача - введение в стране единого документа, удостоверяющего личность, в конце 1920-х годов не была решена.

\section{АДРЕСНЫЕ СТОЛЫ (БЮРО). ПРОПИСКА НАСЕЛЕНИЯ В ГОРОДСКИХ ПОСЕЛЕНИЯХ РСФСР (1925 Г.)}

В рамках легитимации в городах РСФСР (в зависимости от численности населения города) в 1924 г. были организованы адресные столы или адресные бюро, задача которых состояла в точной регистрации и учете населения и выдаче адресных справок [Положение об адресных бюро... 1924: 60]. Правила прописки населения в городских поселениях РСФСР были определены законом 1925 г. [СУ РСФСР 1925: №28: Ст.197: 355-356].

\footnotetext{
${ }^{3}$ В литературе мы не нашли сведений о числе лиц, получивших удостоверение личности.
} 
Каждый прибывший на жительство в дом, находившийся в пределах городского поселения, в том числе и на временное проживание (на срок более 3 дней), был обязан немедленно заявить о своем пребывании домовому управлению (владельцу или арендатору) дома, гостиницы или меблированных комнат, предоставив один из документов, удостоверяющих личность. Домоуправление в свою очередь в течение 48 часов вносило сведения о прибывшем в домовую книгу, и эта запись регистрировалась в соответствующем отделении милиции. Следовательно, прописка в городских поселениях была обязательной, охватывая все виды территориального передвижения. В случае отсутствия необходимых документов допускалась временная прописка на срок не более 3 месяцев. Соответственно выбытие обязывало домовое управление в двухдневный срок сделать отметку в домовой книге и зарегистрировать его в соответствующем отделении милиции. Невыполнение домовладельцами, арендаторами домов и ответственными лицами процедуры прописки влекло за собой в городах предупреждение или денежные взыскания в административном порядке в размере не свыше 25 руб. (или принудительные работы на срок не свыше 10 дней), в сельских местностях предупреждение или штраф не свыше 3 руб. (или принудительные работы не свыше 5 дней) [Турубинер 1930: 187].

Адресные листки на прибывающих составлялись на: а) всех вновь прибывших в город; б) всех достигших 16-летнего возраста; в) всех переменивших место жительство в пределах города; г) всех изменивших фамилию. Заполнение листков для выбывших распространялось на: а) всех выбывших за пределы города; б) всех умерших в городе; в) всех переменивших место жительства в пределах города; г) всех переменивших фамилию в данном городе. Адресные листки включали основные сведения о прибывших и выбывших [Циркуляр №423 1926: 283-286].

Предполагалось, что в дальнейшем прописка (1925 г.) с учетом местных условий и по инициативе местных властей должна будет распространиться на отдельные крупные сельские поселения [СУ РСФСР 1927: № 48: Ст.326: 577].

Для прописки предъявлялись перечисленные выше документы, удостоверявшие личность. В случае их отсутствия допускалась временная (не более 3 месяцев) прописка. Несмотря на тотальный характер прописки, в целом ее правила оценивались как закрепление системы легитимизации. Постепенно другие учреждения переставали требовать предъявления удостоверения личности [Турубинер 1930: 186].

Сложно оценить эффективность действия закона о прописке. Очевидно, что часть населения предпочитала не вступать в контакты с органами власти. С другой стороны, в ряде местностей прописка ограничивалась в силу ряда причин. Из-за высокого уровня безработицы и нараставшего жилищного кризиса в ряде городов на биржах труда не регистрировались безработные из деревни. Однако в 1926 г. биржи труда ввели регистрацию лиц, не имевших в удостоверениях личности отметки о прописке [Циркуляр НКТ СССР 1926: 2]. Заметим, что такая мера позволила определить действительные масштабы безработицы.

Введение прописки в городах выявило недооценку органами НКВД сложности сбора и обработки информации, полученной адресными столами (бюро). Так, Центральное административное управление НКВД РСФСР предписывало до 15 января 1925 г. 
предоставить помесячные сведения о числе прибывших и выбывших в губернских и уездных городах за период с 1 января по 1 декабря 1924 г. [Циркуляр №579 1925: 4]. Такие сроки разработки материалов нередко оказывались невыполненными.

В то же время, как мы уже отмечали, после введения прописки в городах (1925 г.) органы милиции ужесточили требования к документам, удостоверяющим личность. Такие требования усилились в конце 1920-х годов. С 1928 г. была повышена ответственность граждан за предъявление при прописке чужих документов, подделку документов, сообщение ложных сведений в письменном заявлении [Постановление СНК РСФСР 1928а: 37]. В этом же году (1928 г.) была запрещена выдача удостоверений личности и прописка по старым паспортам и трудовым книжкам [Циркуляр НКВД №117 1928: 197].

С учетом усложнявшихся общественно-политических условий по согласованию с ЦСУ РСФСР в 1929 г. в адресный листок был включен вопрос о социальном составе мигрантов [Циркуляр №435 1929: 7].

Для «достижения наиболее точных результатов регистрации и учета городского населения〉 в 1928 г. была впервые установлена административная ответственность граждан за несвоевременную прописку в городских поселениях [Постановление СНК РСФСР 1928b: 333]. Однако в первой половине 1929 г. в составе нарушений, преследуемых в административном порядке, удельный вес нарушений, связанных с нарушением правил учета и регистрации населения, был низким (2,6\%) [Якубсон 1930: 102]. Из этого факта можно заключить, что органы НКВД в рассматриваемое время не контролировали в полной мере соблюдение правил учета и регистрации населения.

В 1929 г. была предпринята попытка «рационализировать» прописку и учет механического движения населения в городах для «разгрузки органов милиции» с помощью новых форм адресных листков. С 1 декабря 1929 г. по 1 марта 1930 г. в 15 городах РСФСР (в Москве, Рязани, Армавире и др.) планировалась упрощенная схема обработки адресных листков, которые должны были пересылаться в адресные бюро (столы), минуя отделения милиции [Циркуляр №23 1929: 733]. Но уже в январе 1930 г. этот циркуляр без объяснения причин был отменен [Циркуляр №107 1930: 17-18]. Новая форма адресных листков (с дополнительными вопросами о национальности, грамотности и избирательных правах граждан) была сохранена.

По-видимому, в рамках формировавшейся новой стратегии была организована проверка работы адресных бюро (столов), выявившая «крупные недочеты» в работе органов НКВД. В 1930 г. они состояли в отсутствии прописки населения в ряде городов и населенных пунктов, предусмотренной законом 1925 г., ходатайств со стороны отдельных крупных сельских поселений о введении прописки и др. В части адресных бюро (столов) использовались адресные листки старых форм без отрывных талонов, не пригодных для разработки статистическими органами. Был выявлен значительный недоучет выбывшего населения. Проверка показала наличие «совершенно неучтенного населения», т.е. не прописанного в городах. Последний недостаток был принципиальным с точки зрения эффективности закона о прописке. Но судя по стандартному набору организационнотехнических мер, циркуляр НКВД 1930 г. по-прежнему опирался на закон 1925 г. Более того, с 1 января 1931 г. прописка, помимо крупных сельских населенных мест, должна была 
охватить остальные сельские населенные места [Циркуляр НКВД №419 1930: 572-574]. Как видим, в начале 1931 г. прописке уделялось возрастающее внимание и предусматривалось ее экстенсивное действие на всей территории РСФСР.

Неудовлетворительное состояние прописки населения подтвердили региональные проверки. В 1930 г. В Нижне-Волжском крае были выявлены хаотичная работа адресных столов, отсутствие учета движения населения в ряде районов и т.д. Обследование показало необходимость упорядочения циркуляров, распоряжений, инструкций НКВД, связанных с работой адресных столов [Трикшеев 1930: 52-53].

Изложенное выше позволяет сделать вывод о повышении в конце 1920-х годов внимания государственных органов к контролю за возраставшими масштабами движения населения. Особое значение имели перемещения социальных групп населения, классово чуждых советской власти - кулаков, зажиточных крестьян, мигрировавших в города после начала коллективизации, «лишенцев» и членов их семей, т.е. граждан СССР, не имевших права участвовать в выборах и быть избранными в органы государственной власти, а также бывших нэпманов.

Состав «лишенцев» был определен в Конституции (Основном Законе 1918 г.) [История советской Конституции... 1957: 155]. Но проведение каждой выборной кампании в СССР дополнялось правилами (инструкциями) о новом учете состава «лишенцев». В конце 1920-х годов был поставлен вопрос об упорядочении учета этой категории населения.

Согласно итогам выборов 1929 г. в советы городов и рабочих поселков РСФСР 727 365 человек (7,2\% общего числа избирателей) были лишены избирательного права, в то время как в 1924-1925 гг. удельный вес «лишенцев» составлял 5,1\%, в 1925-1926 гг. - 4,4\%, в 1927 г. - 7,0\% [Итоги выборов... 1930: 4]. В 1929 г. в состав «лишенцев» были включены лица, прибегавшие к наемному труду (4,5\%), жившие на нетрудовой доход $(10,1 \%)$, торговцы и посредники $(38,4 \%)$, служители религиозных культов $(4,0 \%)$, агенты бывшей полиции и жандармерии $(3,6 \%)$, осужденные судом $(4,6 \%)$, умалишенные и подопечные $(1,8 \%)$ и члены семей «лишенцев» (35,0 \%) [Власов 1930: 19-20]. Но учет «лишенцев» был признан неточным, поскольку определялся со слов самих «лишенцев». Характерным было их расселение - в основном в пригородах городов, где отсутствовали адресные бюро, а также в небольших городах с незначительным притоком населения [Ходос 1930: 75-76].

В итоге в конце 1920-х годов состояние прописки в городских поселениях, введенной в 1925 г., так же как и введение единого документа, удостоверяющего личность, оценивалось как неудовлетворительное.

\section{УЧЕТ ВНУТРЕННЕЙ МИГРАЦИИ}

Необходимость организации учета миграции нашла отражение в Положении о государственной статистике в РСФСР и Положении о губернских статистических бюро (1918 г.) [Положение об организации... 1919: 5-10]. Однако проведение переписей населения и организация регистрации естественного движения были признаны первоочередными задачами отдела демографии ЦСУ РСФСР. В.Г. Михайловский не без 
основания считал, что учет механического движения не имел смысла в условиях неизвестной численности населения страны. По этой причине организация текущего учета миграции планировалась после проведения Всероссийской переписи населения [Отчет о работах... 1919: 203]. Поэтому основные выводы о характере миграции в 1920-е годы первоначально основывались на данных переписей населения 1920, 1923 и 1926 г.

Перепись 1926 г. отразила «постоянную миграцию», поскольку критерием продолжительности разрыва данного лица с постоянным местом жительства был принят годичный срок. На этой основе из состава мигрантов был исключен ряд категорий временных мигрантов [Михайловский 1926: 20-21]. Большой интерес представляют данные о составе населения по месту рождения, продолжительности проживания, разработанные по полу, возрасту, народности, положению в занятии и отраслям народного хозяйства, городским поселениям и сельской местности в региональном разрезе, а также крупным городам. Динамика миграционных когорт 1921-1926 гг. относительно точно характеризует миграцию в период нэпа в силу сократившейся смертности населения и незначительных по сравнению с дореволюционным временем масштабов внешней миграции. Сведения о «постоянной миграции» дополнили данные о связи городского населения с землей, полученные с помощью разработки данных семейной карты.

Сводные материалы переписи 1926 г. о миграции в СССР, опубликованные в 1931 г. (в период коренных изменений в характере этого процесса) остались практически не востребованными современниками. В то же время после 1926 г. выросла потребность в данных текущего учета о миграции для регионального исчисления населения. Однако сведения адресных столов о миграции успешно анализировались только в отдельных городах. Так, анализ механического прироста населения Петрограда за 1925 г., «очищенного» от внутригородских перемещений, показал большие аналитические возможности текущего учета при оценке масштабов, сезонности, структуры и результатов миграции [Паевский 1925-1926: 220-233].

В 1927-1928 гг. был организован «опытный учет миграции» в 14 крупных городах СССР (с населением свыше 100 тыс. человек). В 1927 г. разработка данных текущего учета миграции была включена в план отдела статистики социального состава и движения населения ЦСУ РСФСР: отсутствие опыта не позволяло «сразу же ввести наблюдения во всех городах» [Краснов 1929a: 125].

Сведения, полученные за апрель 1927 г. в 10 крупных городах СССР, включали три формы. Первая показала общее число прибывших и выбывших, подразделявшихся по полу и двум возрастным группам - до 16 лет и старше 16 лет, а также количество переменивших место жительства в пределах города, умерших в городе, достигших 16 лет и изменивших фамилию. В двух других формах прибывшие и выбывшие распределялись в зависимости от места прибытия (выбытия), а также по 45 профессиональным и социальным группам [Лубны-Герцык 1927: 80]. На наш взгляд, «опытный учет миграции» в 1927 г. был усложнен разработкой второстепенного по отношению к миграции материала. 
Результаты «опытного учета миграции» населения в крупных городах СССР в конце 1920-х годов привлекли большое внимание современников. Но полученные сведения были фрагментарны. Текущий учет миграции в Москве был введен в сентябре вместо апреля 1927 г. [Лубны-Герцык 1927: 95]. Во всей группе городов был признан существенным недоучет выбывших (другие вопросы учета, учитывая неудовлетворительное состояние прописки, не рассматривались). В 1928 г. текущий учет миграции должен был охватить 49 городов или 47,8\% городского населения РСФСР. При этом территориальная дифференциация «охвата» миграции текущим учетом колебалась от $10 \%$ в Западной области до 75,6\% в Ленинградской области. Более успешно текущий учет был налажен в городах с населением свыше 100 тыс. человек $(98,4 \%)$ [Краснов 1929a: 125]. По другим данным, статистика миграции в конце 1920-х годов основывалась на сведениях, полученных 54 адресными бюро в крупных городах РСФСР. В 1930 г., как предполагалось, число адресных бюро должно было достичь 360, что позволило бы охватить $75 \%$ городского населения РСФСР. Нерешенным оставался вопрос учета миграции в сельской местности. Планировавшееся статистическим сектором Госплана РСФСР и, по-видимому, не реализованное анкетное обследование должно было определить приблизительные размеры и причины прибытия (выбытия) населения в сельских местностях [Ходос 1930: 75 76]. Как видим, статистические органы пытались ускорить организацию текущего учета миграции. Но эта задача, в конце 1920-х годов зависевшая от состояния прописки (выписки), оставалась нереализованной. В 1930 г. состояние организации учета миграции в стране оценивалось пессимистически. «Наша молодая статистика механического движения населения (насчитывающая всего несколько лет существования) не дает еще, к сожалению, полного освещения миграционных процессов» [Ходос 1930: 75-76]. В итоге кардинальные решения в области регулирования миграции в начале 1930-х годов принимались в условиях отсутствия необходимых сведений о характере миграции. Правда, благодаря налаженной статистике безработицы и жилья в городах важнейшие последствия миграции были в центре внимания. Учитывая региональные особенности, наличие кадров в органах статистики и НКВД, речь могла идти о поэтапной организации текущего учета миграции. Но такая стратегия требовала определенного времени и средств, а главное, признания объективного характера миграции, что противоречило официально принятому представлению о миграции как плановом процессе. Следовательно, задачи организации текущего учета миграции, адресных столов (адресных бюро) и прописки в городских поселениях остались также невыполненными.

\section{ХАРАКТЕР МИГРАЦИИ ИЗ СЕЛА В ГОРОД}

После пертурбационных процессов в движении населения, характерных для 1914-1921 гг., переход к нэпу сопровождался быстрым восстановлением и ростом численности городского населения. В города возвратилось население, покинувшее их в период войн, голода, разрухи и передела земли. В город мигрировали также пролетаризированные слои крестьянства, хотя расширенное воспроизводство аграрного сектора в восстановительный период «удерживало» в деревне часть населения. Но уже в начале 1920-х годов стало заметным увеличение масштабов отхода крестьян на заработки в города и рост численности сельского населения, стремившегося переселиться в многоземельные районы. Проблема 
аграрного перенаселения заняла ключевое место в политике государства и в дискуссиях о перспективах ее решения. В изменившихся после октября 1917 г. общественных условиях характер миграции из деревни в город определялся политикой государства в отношении темпов восстановления и развития индустриальных отраслей, цен на промышленную и сельскохозяйственную продукцию, состояния рынка труда, возраставшей дифференциация крестьянства, переселений и др.

Состояние учета населения, в первую очередь миграции, позволяло оценивать итоги движения населения в обобщенном виде. Так, в первой половине 1920 -х годов на основе данных переписей в отличие от дореволюционного периода была проанализирована динамика роста городов.

Численность населения сопоставимой группы городов Европейской части РСФСР в 1923 г. по отношению к 1897 г. составила 120,4\%, в том числе Петрограда и Москвы - 110\%, прочих городов потребляющей полосы - 126,1\%, производящей полосы - 125,6\%. По сравнению с 1920 г. прирост (убыль) населения в столицах составил 50,8\%, прочих городов потребляющей полосы - 15,2\%, в то время как убыль (из-за голода 1921 г.) городов производящей полосы - 2,6\%. В целом кризис 1918-1920 гг. в столицах был отмечен «большой колеблемостью» численности населения. Население других городов было более устойчивым [Квиткин 1923: 12-15].

Приведенные данные свидетельствовали об ускорившейся урбанизации страны. Особенно быстро росло население промышленных центров. Из 30 городов СССР с населением свыше 100 тыс. человек особенно быстро выросло население Новосибирска (160,9\%), Иваново-Вознесенска (154,2\%), Ленинграда (150,4\%), Днепропетровска $(148,4 \%)$, Сталинграда (138,3\%), Москвы (130,8\%).

Масштабы миграции из деревни в город за 1923-1926 гг. были признаны огромными. Согласно приблизительным оценкам, за 1923-1926 гг. в города СССР переместилось не менее 3 млн человек. В ежегодном исчислении миграционный прирост составил 800 тыс. человек, что оказалось существенно больше приведенных выше данных в довоенное время, несмотря на сокращение численности населения и территории страны [Квиткин 1927: 16].

Перепись 1926 г. выявила превышение роста городского населения по сравнению с плановыми расчетами, а также исчислениями ЦСУ СССР. Такие расхождения отразили новый подход к планированию миграции, недоучитывавший ее реальные тенденции и исходивший из планируемой потребности в рабочей силе.

Динамику численности населения крупных городов определили когорты мигрантов, прибывшие в 1921-1926 гг. Так, удельный вес неместных уроженцев в Ленинграде в 1926 г. составил 60,2\%. Число прибывших в 1921-1923 гг. достигло 172,4 тыс., в 1924 г. - 93,4 тыс., в 1925 г. - 90,3 тыс., в 1926 г. - 113,0 тыс., составив 48,3\% всех неместных уроженцев города [Всесоюзная перепись... 1930а: 150]. В Москве эти показатели были соответственно 312,7 тыс. человек, 106,1 тыс., 91,1 тыс., 93,3 тыс. или 45,2\% неместных уроженцев города [Всесоюзная перепись... 1930b: 173].

Закономерность миграции в середине 1920-х годов состояла в тесной связи горожан с деревней: при неблагоприятных условиях они уходили в деревню, при улучшении 
хозяйственных условий возвращались в город. В Ленинграде $8,0 \%$ семей и $18,3 \%$ одиночек, имевших надельную землю, были тесно связаны с деревней. В Москве эти показатели были соответственно 9,6 и 25,0\%. Несмотря на заметные колебания, ни одна из рабочих групп Ленинграда, включая квалифицированных рабочих, не освободилась от связей с деревней [Красильников 1929: 110]. Под влиянием коллективизации и законов, регулировавших передвижения в начале 1930-х годов, двусторонние миграционные связи города и деревни нарушатся.

Помимо переписи 1926 г., существенный приток населения в крупные города подтвердили фрагментарные данные текущего учета за 1927-1928 гг., о котором шла речь выше. В итоге тенденции миграции в городах во второй половине 1920-х годов оценивались как «повторение общей картины», сложившейся в дореволюционной России [Краснов 1929a: 128].

В 1927 г. текущий учет миграции в городах РСФСР зафиксировал 2155900 прибывших и 1488340 выбывших, миграционный прирост достиг 667500 тыс. человек, что в относительных показателях на 100 человек среднегодового населения равнялось 23,0 прибывших, 16,2 выбывших и 6,8 миграционного прироста. При этом была повторно отмечена несвоевременность и неточность учета выбывшего населения, стремившегося скрыть свое отсутствие и сохранить за собой право на жилую площадь, в то время как прибывшие оформляли своевременно прописку из-за недостатка жилья и «планового снабжения населения продуктами» [Краснов 1929а: 132]. Не могла не настораживать динамика миграционного прироста в ряде крупных городов. В 1929 г. миграционный прирост Ленинграда достиг 126718 человек по сравнению с 86924 в 1928 г., что объяснялось расширением сферы применения труда женщин и притоком несамодеятельной части семьи (домашних хозяек) к лицам, ранее прибывшим в город [Паевский 1930: 77]. Помимо значительных размеров притока, текущий учет выявил сезонный характер миграции и дифференциацию крупных городов в зависимости от показателей миграции. Но во всех крупных городах определяющим был приток населения из сельской местности «своего района» и «своей» республики. Рост городов РСФСР за счет пришлого населения был более значительным по сравнению с городами других республик СССР [Грехов 1928: 96-106].

Рост городов после введения нэпа, в первую очередь крупных, дополненный возраставшим сезонным притоком отходников, привлек внимание органов НКТ, НКВД, ВЦСПС и др. Отголоском военного коммунизма стало запрещение, как мы отмечали, въезда в отдельные районы. Так, приток безработных на территорию Алданских приисков был запрещен из-за трудностей в снабжении продовольствием этой территории [СУ РСФСР 1924: №83: Ст.832: 1188]. Жилищный кризис в 1925 г. предлагалось решить с помощью «временного ограничения иммиграции в крупные города» - предложения, встретившего «практические и правовые препятствия к своему осуществлению» [Бернацкий 1925: 36-55].

Реакцией на рост городов и связанный с ним высокий уровень безработицы и жилищный кризис в 1923-1926 гг. стала агитационная кампания. Судя по циркулярам, постановлениям, циркулярным письмам, принятым НКТ, НКВД, ВЦСПС, интересам органам управления противоречил «непрекращающийся приток» в крупные 
промышленные центры, в первую очередь Москву и Ленинград. В этих условиях местные органы труда, сельсоветы в районах выхода должны были проводить разъяснительную политику по «сокращению» («предотвращению») притока (наплыва) в города. Одним из средств агитации было предостережение относительно трудностей поиска работы и жилья, ожидающих мигрантов в городах.

В обращении НКТ РСФСР к безработным инженерам, агрономам и техникам (1923 г.) отмечается тяжелое материальное положение, ожидающее эти группы населения в Москве, как и дальнейшее ухудшение положения безработных в городе вследствие их притока [Циркуляр НКТ... 1923: 3]. Другое обращение НКТ РСФСР и ВЦСПС призывает местные органы по труду с помощью информации о состоянии рынка труда предотвратить приток в крупные города отходников, демобилизованных из армии, безработных из других регионов [Циркуляр НКТ РСФСР... 1925: 49-50]. «Не прекращавшийся приток» в Москву, Ленинград, Крым и на Дальний Восток демобилизованных красноармейцев, «несмотря на неоднократные предупреждения о безработице», предлагается уменьшить с помощью «широкой разъяснительной компании» о состоянии рынка труда. Биржам труда предписывалось не выдавать льготные билеты для проезда по железной дороге в указанные города и местности, если демобилизованный «не имеет там никакой трудовой или родственной связи» [Циркуляр НКТ РСФСР ... 1926: 25-26].

В 1926 г. «неорганизованные» отходники снова предупреждаются о недопустимости руководствоваться «ложными слухами», недостоверными сведениями о заработках и т.д.

Средством «удержания населения на местах» должны были стать общественные работы для безработных в городах и общественно-мелиоративные работы в деревне [Циркуляр НКТ РСФСР... 1925: 49-50; Циркулярное письмо... 1926: 7] и др. Но значение общественных работ в уменьшении сельской безработицы не могло быть существенным: при недостаточном финансировании к выполнению общественных работ привлекались в первую очередь безработные члены профсоюзов и безработные батраки и пастухи [Циркуляр НКВД РСФСР... 1926: 22].

В 1920-е годы обсуждение причин и последствий миграции из села в город нашло отражение в труднообозримой социально-экономической литературе. Одним из итогов восстановительного периода стало, в частности, повышение и качественное улучшение крестьянского потребления и, как следствие, понижение смертности населения. Но актуальной задачей восстановления «равновесного роста благосостояния городского и сельского населения», насчитывавшего более 24 млн крестьянских хозяйств, оставалось сближение благосостояния городских и сельских жителей, эта проблема считалась «далеко не разрешенной» [Огановский 1927: 41-42].

В связи с этим современники обратили внимание на принципиально изменившиеся в 1920-е годы факторы, определявшие миграцию из сельской местности в города: рост заработной платы рабочих, улучшение их жилищных и бытовых условий. Правда, «временные непосредственные впечатления восстановительного периода и жилищной нужды» мешали «ясно и отчетливо осознать глубокое народнохозяйственное значение изменившегося положения рабочего класса в стране» [Макаров 1925: 87]. Этот вывод стал принципиальным в критической оценке пятилетнего плана развертывания народного 
хозяйства в СССР (1926/27-1930/1931 гг.). К сказанному выше добавим возросшие функции городов как культурных и образовательных центров

Критика пятилетнего плана развития народного хозяйства 1926/27-1930/1931 гг., допускавшаяся в 1926-1927 гг., затронула фундаментальные проблемы методологии планирования и задачи пятилетнего плана. Был, в частности, подвергнут сомнению прогноз численности населения, рассчитанный на основе переписи 1920 г. и других «неточностей исходных данных и приемов» [Вайнштейн 1927: 38-39]. Ожидаемый ежегодный миграционный прирост из деревни в города планировался в размере свыше полумиллиона человек [Струмилин 1927: 30]. Этот показатель, как видим, был существенно меньше миграционного прироста городов в 1923-1926 гг. (800 тыс. человек).

Принципиальное значение с точки зрения миграции имели перспективы увеличения благосостояния городского и сельского населения. Согласно бюджетным обследованиям 1924-1925 гг., личный расходный бюджет на душу сельского населения составил 74 руб., в то время как этот же показатель на душу рабочей семьи был 222 руб. С поправкой на сельскохозяйственные цены уровень благосостояния городского населения был в 2,5 раза выше уровня благосостояния сельского населения. В 1925-1926 гг. аналогичный показатель достиг соответственно 229 и 693 руб. К 1930-1931 гг. повышение рассматриваемого показателя планировалось для сельского труда в размере 4,4\%, а для городского - 43,6\%. По мнению Вайнштейна, сближение уровней благосостояния городского и сельского населения должно было ослабить приток безработных из деревни в город и стимулировать развитие сельского хозяйства. В связи с этим коренной ошибкой «всего построения Госплана» была названа проектируемая «прямо противоположная тенденция» [Вайнштейн 1927: 48].

Исходя из концепции равновесия сельского и народного хозяйства, разрабатывавшейся Н. Огановским, пятилетний план 1926/27-1930/1931 гг. должен был предусмотреть несколько более высокий рост товарной части всей суммы крестьянских доходов по сравнению с таким же ростом городских доходов на душу населения. «Только тогда опасность сильного напора избыточного населения деревни на город была бы в значительной степени устранена... Усиление нажима на город может грозить нам только со стороны деревенской бедняцкой и части середняцкой массы, если денежно-товарная доходность этой массы будет понижаться или расти в меньшей степени, чем общий уровень такой же доходности всей деревни и города» [Огановский 1927: 73-74].

Предостережения известных экономистов подтвердили возросшие диспропорции в развитии индустриальных отраслей и сельского хозяйства и огромные масштабы миграции из деревни. Темпы роста городского населения СССР за 1926-1939 гг. превысили в 5 раз дореволюционные. В эти годы среднегодовой миграционный прирост городов достиг 2,5 млн человек. Последний показатель оказался несопоставимым с величиной миграционного прироста городов России начала ХХ века, приведенного выше. В итоге в 1926-1939 гг. миграция из сельской местности в города поглотила естественный прирост сельского населения страны, составив 18,5 млн человек. Численность городского населения СССР выроста с 26,3 млн до 55,9 млн [Сулькевич 1940: 30]. Разрушительные последствия миграции проявились в огромной текучести кадров на промышленных предприятиях, 
строительстве и, как следствие, формировании избыточной рабочей силы предприятиями, ростом городов, усилением жилищного и продовольственного кризиса, потерями частью районов значительной части сельского населения и др.

Как видим, характерной чертой 1920-х годов стал увеличившийся приток сельского населения в города, в то время как по сравнению с дореволюционным временем сократились масштабы отхода крестьян на заработки и переселения в многоземельные районы. С началом форсированной индустриализации масштабы притока увеличила принудительная коллективизация. В условиях «беспрепятственного передвижения» населения выявилось нараставшее противоречие между характером миграции и низкой эффективностью инструментов административного контроля миграции. Помимо непоследовательной политики, связанной с введением удостоверения личности, обнаружились крупные недостатки в организации прописки населения и текущем учете миграции в городах, хотя задачи контроля миграции решалась при низком уровне урбанизации страны. Идеология нового общества оказалась несовместимой со стихийным рынком рабочей силы в крупных городах, стихийным отходничеством, самостоятельными переселениями и др.; в рамках командно-административной экономики легимитационная система не имела перспективы. Опыт ее функционирования выявил противоречивость декретов, постановлений, инструкций и т.д., неустойчивость, зависимость от политикоэкономической конъюнктуры, определив непродолжительный срок существования, а вслед за нэпом - ликвидацию. Решение вопросов, связанных с масштабами и направлением миграции, составом мигрантов, рассматривались как кризис миграционной политики в условиях «беспрепятственного передвижения», который решался с помощью ужесточения административного контроля. Постановление ЦИК СССР и СНК СССР от 27.12.1932 «Об установлении единой паспортной системы по Союзу ССР и обязательной прописки паспортов» [С3 СССР 1932: №84: Ст.516] в СССР устанавливало единую паспортную систему на основании Положения о паспортах. Утверждалось, что в отличие от легимитационной системы паспортная система образца 1932 г. означала «порядок учета, контроля и регулирования передвижения населения посредством введения для последнего паспортов» [Паспортная система 1939: 322].

\section{ЛИТЕРАТУРА}

А.Я. (1897). Паспорт // Энциклопедический словарь. Т. XXII А. СПб.: Ф.А. Брокгауз, И.А. Эфрон: 923-925.

Бернацкий Л.Н. (1925). Жилищный кризис и жилищное строительство // Плановое хозяйство. 5: 36-55.

Большая Советская энциклопедия (1953). 2-е изд. Т.24. М.: 410.

Вайнштейн А.Л. (1927). К критике пятилетнего перспективного плана развертывания народного хозяйства СССР // Экономическое обозрение. 7: 33-67.

Власов В. (1930). Об учете лиц, лишенных избирательных прав // Административный вестник. 2: 18-25.

Воблый К.Г. (1924). Статистика. Пособие для учащихся и самообразования. Изд. 6-ое, переработанное. Киев. 287 с. 
Всесоюзная перепись населения 1926 года (1930а). T.XXXV. М.

Всесоюзная перепись населения 1926 года (1930b). T.XXXVI. M.

Граевский В.И. (1927). Удостоверения личности и прописка граждан // Административный вестник. 1: 39-45.

Грехов В. (1928). Механическое движение население в городах СССР (с 1 апреля 1927 г. по 31 марта 1928 г.) // Статистическое обозрение. 12: 96-106.

Гуров П.Я. (1927). Земельный кодекс РСФСР в вопросах и ответах. Изд. 9-е., дополненное. М.-Л. 343 с.

Дерюжинский В.Ф. (1919). Полицейское право. Пособие для студентов. Изд. 4-е. Пг. 522 с.

Елистратов Е. (1923). Об Административном Кодексе // Власть советов. 3: 29-31.

Инструкция НКВД № 370 об удостоверениях личности и прописке граждан в городских поселениях (1925) // Бюллетень НКВД. 28 (168): 248-250.

История советской Конституции (в документах). 1917-1956 (1957). М. 155 с.

Итоги выборов в советы РСФСР (1930). Вып.11. М. Вып.11. М. 103 с.

Карадже-Искров Н.П. (1927). Новейшая эволюция административного права. Иркутск. $39 \mathrm{c}$.

Квиткин О. (1923). Население городов Европейской части РСФСР по переписям 1897 , 1917, 1920 и 1923 годов // Бюллетень Центрального Статистического Управления. 77: $10-28$.

Квиткин О. (1927). Первые итоги переписи населения 1926 г. // Статистическое обозрение. 1: 13-19.

Кобалевский В.Л. (1929). Советское административное право. Харьков. 419 с.

Красильников М. (1929). Связь ленинградского рабочего с землей // Статистическое обозрение. 4: 107-110.

Краснов П. (1929а). Миграция населения в городах РСФСР в 1928 году // Статистика и народное хозяйство. Статьи и материалы. 8: 125-141.

Краснов П. (1929b). Миграция населения в городах РСФСР в 1928 году // Статистика и народное хозяйство. Статьи и материалы. 9: 111-117.

Лубны-Герцык Л. (1927). Механическое движение населения в 10 городах Союза ССР в апреле 1927 года // Статистическое обозрение. 9: 80-86.

Макаров Н. (1925). К вопросу о взаимоотношении сельского хозяйства и индустрии // Экономическое обозрение. 10: 78-88.

Михайловский А. (1923). Население наших городов // Экономическое обозрение. 5: 24-29.

Михайловский В.Г. (1897). Население России по первой всеобщей переписи // Новое слово. Кн. 9: 97-107.

Михайловский В.Г. (1926). Всесоюзная перепись населения 1926 года. Рекомендуется в качестве материала для проведения переписи населения. М. 28 с.

Народным комиссариатом юстиции. Отдел первый. М.

Огановский Н. (1914). Закономерности аграрной эволюции. Т.ІІІ. Вып. 1. Саратов. 335 с. 
Огановский Н. (1927). Равновесие сельского и народного хозяйства в аспекте перспективного плана // Экономическое обозрение. 3: 21-42.

Отчет о работах Первой статистической конференции при Центральном Статистическом Управлении, состоявшейся 18-21 октября 1918 года (1919) // Вестник статистики. 1: 183-220.

Паевский В. (1925-1926). Механическое движение населения Ленинграда // Бюллетень Ленинградского губернского статистического отдела. 15: 220-233.

Паевский В. (1930). О миграциях населения Ленинграда в 1929 г. // Статистический бюллетень. 25: 73-75.

Паспортная система (1939) // Большая Советская энциклопедия / Гл. ред. О.Ю. Шмидт. M.: 322.

Положение об адресных бюро и адресных столах в РСФСР (1924) // Систематический сборник приказов, инструкций и циркуляров НКВД административного характера, действующих на 1 июля 1924 года. М.: 60.

Положение об организации местных статистических органов (1919) // Вестник статистики. 1: C. 5-10.

Постановление СНК РСФСР (1928а). Об изменении декрета РСФСР от 25 апреля 1925 г. «О прописке граждан в городских поселениях» // Бюллетень НКВД. 2 (257): 37.

Постановление СНК РСФСР (1928b). О дополнении ст. 9 Постановления Совета Народных Комиссаров РСФСР о прописке в городских поселениях // Бюллетень НКВД. 18 (273): 333.

С3 СССР (1932). Собрание законов и распоряжений Рабочего и Крестьянского правительства Союза Советских Социалистических Республик. Отдел первый. М.

Струмилин С.Г. (1927). К перспективной пятилетке Госплана на 1926/27-1930/31 гг. // Плановое хозяйство. 3: 17-54.

СУ (1918). Собрание узаконений и распоряжений рабочего и крестьянского правительства. Отдел первый. М.

СУ (1919). Собрание узаконений и распоряжений рабочего и крестьянского правительства за 1919 год. М.

СУ (1922). Собрание узаконений и распоряжений рабочего и крестьянского правительства, издаваемое Народным комиссариатом юстиции. Отдел первый. М.

СУ (1923). Собрание узаконений и распоряжений рабочего и крестьянского правительства, издаваемое Народным комиссариатом юстиции. Отдел первый. М.

СУ РСФСР (1924). Собрание узаконений и распоряжений рабочего и крестьянского правительства, издаваемое

СУ РСФСР (1925). Собрание узаконений и распоряжений рабочего и крестьянского правительства Российской Социалистической Федеративной Советской Республики, издаваемое Народным комиссариатом юстиции. Отдел первый. М.

СУ РСФСР (1926). Собрание узаконений и распоряжений рабочего и крестьянского правительства Российской Социалистической Федеративной Советской Республики, издаваемое Народным комиссариатом юстиции. Отдел первый. М. 
СУ РСФСР (1927). Собрание узаконений и распоряжений рабочего и крестьянского правительства Российской Социалистической Федеративной Советской Республики, издаваемое Народным комиссариатом юстиции. Отдел первый. М.

Сулькевич С. (1940). Территория и население СССР. М. 71 с.

Трикшеев В. (1930). От правильного учета движения населения зависит правильность государственного управления. (Из практики Нижне-Волжского края) // Административный вестник. 8-9: 52-53.

Турубинер А. (1930). Паспортная система // Энциклопедия государства и права. Т.III / Под ред. П. Стучки. М.: 184 -187.

Ходос М. (1930). Проект схемы конъюнктурных показателей в области явлений социально-культурной жизни // Статистика и народное хозяйство. 3 (12): 64-78.

Циркуляр №107 (1930). Об отмене циркуляра НКВД № 23 от 29 октября 1929 года «О прописке граждан в городских поселениях и с объявлением Положения об адресных бюро и адресных столах в РСФСР // Бюллетень НКВД. 2: 17-18.

Циркуляр №23 (1929). О прописке граждан в городских поселениях и с объявлением «Положения об адресных бюро и адресных столах в РСФСР» // Бюллетень НКВД. 40 (341): 733.

Циркуляр №365 (1926). О порядке выдачи удостоверений личности лицам, коим судом по ст. 49 УК воспрещено проживание в определенных местах и высланных в административном порядке // Бюллетень НКВД. 25 (121): 264-265.

Циркуляр №423 с объявлением «Положения об адресных бюро и адресных столах в РСФСР» (1926) // Бюллетень НКВД. 28 (215): 283-286.

Циркуляр №435 (1929). Об изменении формы адресных листков // Бюллетень НКВД. 1-2 (302-303): 7.

Циркуляр №579 (1925). О предоставлении сведений о движении городского населения с 1 января по 1 декабря 1925 г. // Бюллетень НКВД. 1: 4.

Циркуляр НКВД №117 (1928). О непринятии старых паспортов и трудовых книжек в качестве документов // Бюллетень НКВД. 11 (266): 197.

Циркуляр НКВД №419 (1930). О мерах по улучшению работы адресных бюро (столов) и по прописке населения // Бюллетень НКВД. 27: 572-574.

Циркуляр НКВД РСФСР от 16 ноября 1925 г. (1926). О мероприятиях, направленных к уменьшению безработицы в сельских местностях // Известия НКТ СССР. 2: 22.

Циркуляр НКТ от 18.04.1923 (1923). Ко всем безработным инженерам, агрономам и техникам // Известия НКТ СССР. 15-16: 3.

Циркуляр НКТ РСФСР и ВЦСПС от 14 апреля 1925 г. (1925). О мерах к предупреждению притока безработных в крупные центры // Известия НКТ СССР. 20-21: 49-50.

Циркуляр НКТ РСФСР и ВЦСПС от 14 апреля 1925 г. (1925). О мерах по предупреждению притока безработных в крупные центры // Известия НКТ СССР. 21 22: $49-50$.

Циркуляр НКТ РСФСР и НКВД РСФСР от 20 февраля 1926 г. №37/111 (1926). О предупреждении наплыва мобилизованных в крупные промышленные центры // Известия НКТ СССР. 10-11: 25-26. 
Циркуляр НКТ СССР от 2 октября 1926 г. (1926). О регистрации на бирже труда лиц, не имеющих в удостоверениях личности отметки о прописке // Известия НКТ СССР. 40: 2.

Циркулярное письмо НКТ СССР от 13 февраля 1926 г. (1926). О мероприятиях по организации общественных работ в сельских местностях для притока сельского населения в город // Известия НКТ СССР. 9: 7.

Якубсон (1930). Нарушения, преследуемые в административном порядке // Статистическое обозрение. 5: 93-100. 


\title{
RURAL-URBAN MIGRATION IN THE USSR IN THE $1920 \mathrm{~S}$
}

\section{VALENTINA MOISEENKO}

\begin{abstract}
The paper is devoted to an analysis of migration from village to town in Russia during the 1920s, after the transition to New Economic Policy (NEP) and at the start of accelerated industrialization and collectivization. Great attention to instruments of administrative regulation of migration played a role of great importance in the change in migration policy at the beginning of the 1930s.
\end{abstract}

Keywords: population migration, liberalization of population movement, identity card, population registration, migration record keeping, urbanization, the First five-year plan.

VAlentina M. Moiseenko (mvm.msu@gmail.com), Lomonosov Moscow State University, Russia.

DATE RECEIVED : APRIL 2018.

\section{REFERENCES}

A.Ya. (1897). Pasport [Passport] // Entsiklopedicheskiy slovar' [Encyclopaedical dictionary]. T. XXII A [Vol. XXII A]. Sankt-Peterburg: F.A. Brokgauz, I.A. Efron: 923-925.

Bernatskiy L.N. (1925). Zhilishchnyy krizis i zhilishchnoe stroitel'stvo [Housing crisis and housing construction] // Planovoe khozyaystvo [State-planned economy]. 5: 36-55.

Bol'shaya Sovetskaya entsiklopediya [Great Soviet Encyclopedia] (1953). 2-e izd. [Second edition]. T.24. [Vol.24]. Moscow: 410.

Deryuzhinskiy V.F. (1919). Politseyskoe pravo. Posobie dlya studentov [Police law. Textbook for students]. Izd. 4-e [Fourth edition]. Petrograd. 522 p.

Elistratov E. (1923). Ob Administrativnom Kodekse [About the Administrative Code] // Vlast' sovetov [Soviet rule]. 3: 29-31.

Graevskiy V.I. (1927). Udostovereniya lichnosti i propiska grazhdan [Identity cards and citizenship] // Administrativnyy vestnik [Administrative Herald]. 1: 39-45.

Grekhov V. (1928). Mekhanicheskoe dvizhenie naselenie v gorodakh SSSR (s 1 aprelya $1927 \mathrm{~g}$. po 31 marta $1928 \mathrm{~g}$.) [Mechanical movement of the population in the cities of the USSR (from April 1, 1927 to March 31, 1928)] // Statisticheskoe obozrenie [Statistical Review]. 12: 96-106.

Gurov P.Ya. (1927). Zemel'nyy kodeks RSFSR v voprosakh i otvetakh [The Land Code of the RSFSR in questions and answers]. Izd. 9-e., dopolnennoe [Ninth edition]. MoscowLeningrad. $343 \mathrm{p}$.

Instruktsiya NKVD № 370 ob udostovereniyakh lichnosti i propiske grazhdan v gorodskikh poseleniyakh [Instruction of the NKVD No. 370 on identity cards and registration of citizens in urban settlements] (1925) // Byulleten' NKVD [Bulletin of the NKVD]. 28 (168): 248-250.

Istoriya sovetskoy Konstitutsii (v dokumentakh). 1917-1956 [History of the Soviet Constitution (in documents). 1917-1956] (1957). Moscow. 155 p.

Itogi vyborov v sovety RSFSR [Results of the elections to the councils of RSFSR] (1930). Vyp.11 [Issue11]. Moscow. 103 p.

Karadzhe-Iskrov N.P. (1927). Noveyshaya evolyutsiya administrativnogo prava [The newest evolution of administrative law]. Irkutsk. 39 p. 
Khodos M. (1930). Proekt skhemy kon"yunkturnykh pokazateley v oblasti yavleniy sotsial'nokul'turnoy zhizni [The project of the scheme of conjuncture indicators in the field of social and cultural life] // Statistika i narodnoe khozyaystvo [Statistics and National Economy]. 3 (12): 64-78.

Kobalevskiy V.L (1929). Sovetskoe administrativnoe pravo [Soviet Administrative Law]. Kharkov. 419 p.

Krasilnikov M. (1929). Svyaz' leningradskogo rabochego s zemley [The connection of the Leningrad worker to the land] // Statisticheskoe obozrenie [Statistical Review]. 4: 107-110.

Krasnov P. (1929a). Migratsiya naseleniya v gorodakh RSFSR v 1928 godu [Migration of the population in the cities of RSFSR in 1928] // Statistika i narodnoe khozyaystvo. Stat'i i materialy [Statistics and national economy. Articles and materials]. 8: 125-141.

Krasnov P. (1929b). Migratsiya naseleniya v gorodakh RSFSR v 1928 godu [Migration of the population in the cities of RSFSR in 1928] // Statistika i narodnoe khozyaystvo. Stat'i i materialy [Statistics and national economy. Articles and materials]. 9: 111-117.

Kvitkin O. (1923). Naselenie gorodov Evropeyskoy chasti RSFSR po perepisyam 1897, 1917, 1920 i 1923 godov [The population of cities in the European part of RSFSR according to the censuses of 1897, 1917, 1920 and 1923] // Byulleten' Tsentral'nogo Statisticheskogo Upravleniya [Bulletin of the Central Statistical Bureau]. 77: 10-28.

Kvitkin O. (1927). Pervye itogi perepisi naseleniya $1926 \mathrm{~g}$. [The first results of the 1926 population census] // Statisticheskoe obozrenie [Statistical Review]. 1: 13-19.

Lubny-Gertsyk L. (1927). Mekhanicheskoe dvizhenie naseleniya v 10 gorodakh Soyuza SSR v aprele 1927 goda [Mechanical movement of the population in 10 cities of the USSR in April 1927] // Statisticheskoe obozrenie [Statistical Review]. 9: 80-86.

Makarov N. (1925). K voprosu o vzaimootnoshenii sel'skogo khozyaystva i industrii [On the issue of the relationship between agriculture and industry] // Ekonomicheskoe obozrenie [Economic Review]. 10: 78-88.

Mikhaylovskiy A. (1923). Naselenie nashikh gorodov [The population of our cities] // Ekonomicheskoe obozrenie [Economic Review]. 5: 24-29.

Mikhaylovskiy V.G. (1897). Naselenie Rossii po pervoy vseobshchey perepisi [Population of Russia in the first general census] // Novoe slovo [New word]. Kn. 9 [Book 9]: 97-107.

Mikhaylovskiy V.G. (1926). Vsesoyuznaya perepis' naseleniya 1926 goda. Rekomenduetsya v kachestve materiala dlya provedeniya perepisi naseleniya [All-Union Population Census of 1926. Recommended as a material for a population census]. Moscow. $28 \mathrm{p}$.

Oganovskiy N. (1914). Zakonomernosti agrarnoy evolyutsii [Regularities of agrarian evolution]. T.III [Vol. III]. Vyp. 1 [Issue 1]. Saratov. 335 p.

Oganovskiy N. (1927). Ravnovesie sel'skogo i narodnogo khozyaystva v aspekte perspektivnogo plana [Equilibrium of the rural and national economy in the aspect of the long-term plan] // Ekonomicheskoe obozrenie [Economic Review]. 3: 21-42.

Otchet o rabotakh Pervoy statisticheskoy konferentsii pri Tsentral'nom Statisticheskom Upravlenii, sostoyavsheysya 18-21 oktyabrya 1918 goda [Report on the work of the First Statistical Conference at the Central Statistical Office, held in October 18-21, 1918] (1919) // Vestnik statistiki [Herald of Statistics]. 1: 183-220.

Paevskiy V. (1925-1926). Mekhanicheskoe dvizhenie naseleniya Leningrada [Mechanical movement of the population of Leningrad] // Byulleten' Leningradskogo gubernskogo 
statisticheskogo otdela [Bulletin of the Leningrad provincial statistical department]. 15: 220233.

Paevskiy V. (1930). O migratsiyakh naseleniya Leningrada v 1929 g. [On the migration of the population of Leningrad in 1929] // Statisticheskiy byulleten' [Statistical Bulletin]. 25: 73-75.

Pasportnaya sistema [Passport system] (1939) // Bol'shaya Sovetskaya entsiklopediya [Great Soviet Encyclopedia] / O.Yu. Shmidt, ed. Moscow: 322.

Polozhenie ob adresnykh byuro i adresnykh stolakh v RSFSR [Regulation on address bureaus and address desks in the RSFSR] (1924) // Sistematicheskiy sbornik prikazov, instruktsiy i tsirkulyarov NKVD administrativnogo kharaktera, deystvuyushchikh na 1 iyulya 1924 goda [A systematic collection of orders, instructions and circulars of the NKVD of an administrative nature, in force as of July 1, 1924]. Moscow: 60.

Polozhenie ob organizatsii mestnykh statisticheskikh organov [Regulations on the organization of local statistical bodies] (1919) // Vestnik statistiki [Herald of Statistics]. 1: C. 5-10.

Postanovlenie SNK RSFSR [Resolution of the Council of People's Commissars of the RSFSR] (1928a). Ob izmenenii dekreta RSFSR ot 25 aprelya 1925 g. "O propiske grazhdan V gorodskikh poseleniyakh» [On the amendment of the decree of the RSFSR of April 25, 1925 "On the registration of citizens in urban settlements"] // Byulleten' NKVD [Bulletin of the NKVD]. 2 (257): 37.

Postanovlenie SNK RSFSR [Resolution of the Council of People's Commissars of the RSFSR] (1928b). O dopolnenii st. 9 Postanovleniya Soveta Narodnykh Komissarov RSFSR o propiske $\mathrm{v}$ gorodskikh poseleniyakh [On the addition of Art. 9 Decisions of the Council of People's Commissars of the RSFSR on registration in urban settlements] // Byulleten' NKVD [Bulletin of the NKVD]. 18 (273): 333.

Strumilin S.G. (1927). K perspektivnoy pyatiletke Gosplana na 1926/27-1930/31 gg. [To the prospective five-year plan of the State Planning Committee for 1926 / 27-1930 / 31] // Planovoe khozyaystvo [State-planned economy]. 3: 17-54.

SU [Code of justice] (1918). Sobranie uzakoneniy i rasporyazheniy rabochego i krest'yanskogo pravitel'stva [Code of justice and orders of the workers 'and peasants' government]. Otdel pervyy [Отдел первый]. Moscow.

SU [Code of justice] (1919). Sobranie uzakoneniy i rasporyazheniy rabochego i krest'yanskogo pravitel'stva za 1919 god [Code of justice and orders of the workers 'and peasants' government 1919]. Moscow.

SU [Code of justice] (1922). Sobranie uzakoneniy i rasporyazheniy rabochego i krest'yanskogo pravitel'stva, izdavaemoe Narodnym komissariatom yustitsii [Code of justice and orders of the workers 'and peasants' government, issued by the People's Commissariat of Justice]. Otdel pervyy [First Division]. Moscow.

SU [Code of justice] (1923). Sobranie uzakoneniy i rasporyazheniy rabochego i krest'yanskogo pravitel'stva, izdavaemoe Narodnym komissariatom yustitsii [Code of justice and orders of the workers 'and peasants' government, issued by the People's Commissariat of Justice]. Otdel pervyy [First Division]. Moscow.

SU RSFSR [Code of justice of the RSFSR] (1924). Sobranie uzakoneniy i rasporyazheniy rabochego i krest'yanskogo pravitel'stva, izdavaemoe Narodnym komissariatom yustitsii [Code of justice and orders of the workers 'and peasants' government, issued by the People's Commissariat of Justice]. Otdel pervyy [First Division]. Moscow. 
SU RSFSR [Code of justice of the RSFSR] (1925). Sobranie uzakoneniy i rasporyazheniy rabochego i krest'yanskogo pravitel'stva Rossiyskoy Sotsialisticheskoy Federativnoy Sovetskoy Respubliki, izdavaemoe Narodnym komissariatom yustitsii [Code of justice and orders of the workers 'and peasants' government of the RSFSR, issued by the People's Commissariat of Justice]. Otdel pervyy [First Division]. Moscow.

SU RSFSR [Code of justice of the RSFSR] (1926). Sobranie uzakoneniy i rasporyazheniy rabochego i krest'yanskogo pravitel'stva Rossiyskoy Sotsialisticheskoy Federativnoy Sovetskoy Respubliki, izdavaemoe Narodnym komissariatom yustitsii [Code of justice and orders of the workers 'and peasants' government of the RSFSR, issued by the People's Commissariat of Justice]. Otdel pervyy [First Division]. Moscow.

SU RSFSR [Code of justice of the RSFSR] (1927). Sobranie uzakoneniy i rasporyazheniy rabochego i krest'yanskogo pravitel'stva Rossiyskoy Sotsialisticheskoy Federativnoy Sovetskoy Respubliki, izdavaemoe Narodnym komissariatom yustitsii [Code of justice and orders of the workers 'and peasants' government of the RSFSR, issued by the People's Commissariat of Justice]. Otdel pervyy [First Division]. Moscow.

Sulkevich S. (1940). Territoriya i naselenie SSSR [Территория и население CCCP]. Moscow. $71 \mathrm{p}$.

SZ SSSR [Code of laws of the USSR] (1932). Sobranie zakonov i rasporyazheniy Rabochego i Krest'yanskogo pravitel'stva Soyuza Sovetskikh Sotsialisticheskikh Respublik [Code of laws and orders of the workers 'and peasants' government of the USSR]. Otdel pervyy [First Division]. Moscow.

Triksheev V. (1930). Ot pravil'nogo ucheta dvizheniya naseleniya zavisit pravil'nost' gosudarstvennogo upravleniya. (Iz praktiki Nizhne-Volzhskogo kraya) [The correctness of public administration depends on correct consideration of population movements. (From the practice of the Lower Volga region)] // Administrativnyy vestnik [Administrative Herald]. 89: 52-53.

Tsirkulyar NKT ot 18.04.1923 [Circular NCP from 18.04.1923] (1923). Ko vsem bezrabotnym inzheneram, agronomam i tekhnikam [To all unemployed engineers, agronomists and technicians] // Izvestiya NKT SSSR [News of the USSR]. 15-16: 3.

Tsirkulyar NKT RSFSR i NKVD RSFSR ot 20 fevralya 1926 g. №37/111 [Circular NCP of the RSFSR and the NKVD of the RSFSR of February 20, 1926 No. 37/111] (1926). O preduprezhdenii naplyva mobilizovannykh v krupnye promyshlennye tsentry [On preventing the influx of people mobilized to large industrial centers] // Izvestiya NKT SSSR [News of the USSR]. 10-11: 25-26.

Tsirkulyar NKT RSFSR i VTsSPS ot 14 aprelya $1925 \mathrm{~g}$. [Circular NCP of the RSFSR and the All-Union Central Council of Trade Unions of April 14, 1925.] (1925). O merakh k preduprezhdeniyu pritoka bezrabotnykh $\mathrm{v}$ krupnye tsentry [On measures to prevent the influx of unemployed into large centers] // Izvestiya NKT SSSR [News of the USSR]. 20-21: 49-50.

Tsirkulyar NKT RSFSR i VTsSPS ot 14 aprelya $1925 \mathrm{~g}$. [Circular NCP of the RSFSR and the All-Union Central Council of Trade Unions of April 14, 1925.] (1925). O merakh po preduprezhdeniyu pritoka bezrabotnykh $\mathrm{v}$ krupnye tsentry [On measures to prevent the influx of unemployed into large centers] // Izvestiya NKT SSSR [News of the USSR]. 21-22: 49-50.

Tsirkulyar NKT SSSR ot 2 oktyabrya $1926 \mathrm{~g}$. [Circular NCP of the USSR of October 2, 1926.] (1926). O registratsii na birzhe truda lits, ne imeyushchikh v udostovereniyakh lichnosti otmetki o propiske [On registration at the labor exchange of persons who do not have a residence permit in their identity cards] // Izvestiya NKT SSSR [News of the USSR]. 40: 2. 
Tsirkulyar NKVD №117 [Circular of the NKVD №117] (1928). O neprinyatii starykh pasportov i trudovykh knizhek $v$ kachestve dokumentov [On the non-acceptance of old passports and labor books as documents] // Byulleten' NKVD [Bulletin of the NKVD]. 11 (266): 197.

Tsirkulyar NKVD №419 [Circular of the NKVD №419] (1930). O merakh po uluchsheniyu raboty adresnykh byuro (stolov) i po propiske naseleniya [On measures to improve the work of address bureaus (tables) and on the registration of the population] // Byulleten' NKVD [Бюл Bulletin of the NKVD]. 27: 572-574.

Tsirkulyar NKVD RSFSR ot 16 noyabrya 1925 g. [Циркуляр НКВД РСФСР от 16 ноября 1925 г.] (1926). O meropriyatiyakh, napravlennykh k umen'sheniyu bezrabotitsy v sel'skikh mestnostyakh [On measures aimed at reducing unemployment in rural areas] // Izvestiya NKT SSSR [News of the USSR]. 2: 22.

Tsirkulyar №107 [Circular №107] (1930). Ob otmene tsirkulyara NKVD №23 ot 29 oktyabrya 1929 goda «O propiske grazhdan v gorodskikh poseleniyakh i s ob"yavleniem Polozheniya ob adresnykh byuro i adresnykh stolakh v RSFSR [On the abolition of the circular of the NKVD No. 23 of October 29, 1929 "On the registration of citizens in urban settlements and with the announcement of the Regulations on address bureaus and address desks in the RSFSR] // Byulleten' NKVD [Bulletin of the NKVD]. 2: 17-18.

Tsirkulyar №23 [Circular №23] (1929). O propiske grazhdan v gorodskikh poseleniyakh i s ob"yavleniem «Polozheniya ob adresnykh byuro i adresnykh stolakh v RSFSR» [On the registration of citizens in urban settlements and with the announcement of "Regulations on address bureaus and address desks in the RSFSR"] // Byulleten' NKVD [Bulletin of the NKVD]. 40 (341): 733.

Tsirkulyar №365 [Circular №365] (1926). O poryadke vydachi udostovereniy lichnosti litsam, koim sudom po st. $49 \mathrm{UK}$ vospreshcheno prozhivanie v opredelennykh mestakh i vyslannykh $\mathrm{v}$ administrativnom poryadke [On the procedure for issuing identity cards to persons to whom the court under Art. 49 of the Criminal Code is prohibited from living in certain places and sent in administrative order] // Byulleten' NKVD [Bulletin of the NKVD]. 25 (121): 264265.

Tsirkulyar №423 s ob"yavleniem «Polozheniya ob adresnykh byuro i adresnykh stolakh v RSFSR» [Circular No. 423 with the announcement of "Provisions on address bureaus and address desks in the RSFSR"] (1926) // Byulleten' NKVD [Bulletin of the NKVD]. 28 (215): 283-286.

Tsirkulyar №435 [Circular №435] (1929). Ob izmenenii formy adresnykh listkov [About changing the form of address sheets] // Byulleten' NKVD [Bulletin of the NKVD]. 1-2 (302303): 7.

Tsirkulyar №579 [Circular №579] (1925). O predostavlenii svedeniy o dvizhenii gorodskogo naseleniya s 1 yanvarya po 1 dekabrya $1925 \mathrm{~g}$. [On the provision of information on the movement of the urban population from January 1 to December 1, 1925] // Byulleten' NKVD [Bulletin of the NKVD]. 1: 4.

Tsirkulyarnoe pis'mo NKT SSSR ot 13 fevralya $1926 \mathrm{~g}$. [Circular letter of the NCT of the USSR of February 13, 1926.] (1926). O meropriyatiyakh po organizatsii obshchestvennykh rabot v sel'skikh mestnostyakh dlya pritoka sel'skogo naseleniya $\mathrm{v}$ gorod [On activities to organize public works in rural areas for the influx of rural population into the city] // Izvestiya NKT SSSR [News of the USSR]. 9: 7.

Turubiner A. (1930). Pasportnaya Sistema [Passport system] // Entsiklopediya gosudarstva i prava [Encyclopedia of State and Law]. T.III [V.3] / P. Stuchka, ed. Moscow: $184-187$. 
Vaynshteyn A.L. (1927). K kritike pyatiletnego perspektivnogo plana razvertyvaniya narodnogo khozyaystva SSSR [To the criticism of the five-year long-term plan for the development of the national economy of the USSR] // Ekonomicheskoe obozrenie [Economic Review]. 7: 33-67.

Vlasov V. (1930). Ob uchete lits, lishennykh izbiratel'nykh prav [On the account of persons deprived of their voting rights] // Administrativnyy vestnik [Administrative Herald]. 2: 1825 .

Voblyy K.G. (1924). Statistika. Posobie dlya uchashchikhsya i samoobrazovaniya [Statistics. A manual for students and self-education]. Izd. 6-oe, pererabotannoe [Ed. 6th, revised]. Kiev. $287 \mathrm{p}$.

Vsesoyuznaya perepis' naseleniya 1926 goda [All-Union Population Census of 1926] (1930a). T.XXXV [Vol. XXXV]. Moscow.

Vsesoyuznaya perepis' naseleniya 1926 goda [All-Union Population Census of 1926] (1930b). T. XXXVI [Vol. XXXVI]. Moscow.

Yakubson (1930). Narusheniya, presleduemye v administrativnom poryadke [Administrative violations] // Statisticheskoe obozrenie [Statistical Review]. 5: 93-100. 